\title{
Actual Role and Problems of Compensation Management in Croatian Enterprises: an Empirical Study ${ }^{*}$
}

\author{
Lovorka Galetić, Darko Tipurić, Božidar Juri ${ }^{* *}$
}

The article deals with current positions and perspectives of compensation management in Croatian enterprises. To confirm the hypothesis that neither enough attention to compensation management has been paid, nor the influence, which it has on prosperity, efficiency and enterprises 'competitiveness, has been recognized in a sufficient degree in the Republic of Croatia, the authors present an empirical study conducted at the beginning of 1998 on the sample of 139 Croatian enterprises. Various aspects of compensation management from the point of view of the enterprise size, realized financial results of the enterprise, kind and profitability of the enterprise belonging activity have been analyzed.

In diesem Artikel werden aktuelle Positionen und Perspektiven des Managements von Vergütungssystemen in kroatischen Unternehmen dargestellt. Mit dieser empirischen Studie, die Anfang 1998 mit 139 kroatischen Unternehmen durchgeführt wurde, wollen die Autoren die Hypothese belegen, daß dem Management von Vergütungssystemen nicht genügend Aufmerksamkeit zuteil wird. Außerdem wird seine Bedeutung für das Wachstum, die Effizienz und die Wettbewerbsfähigkeit eines Unternehmens unterschätzt. Verschiedene Aspekte des Managements von Vergütungen werden in dieser Studie betrachtet.

\footnotetext{
* Manuscript received: 25.02.1999, revised: 02.11.1999, accepted:04.11.1999;

** Lovorka Galetić and Darko Tipurić, Faculty of Economics, University of Zagreb, Croatia; Božidar Juri, Faculty of Graphic Arts, University of Zagreb, Croatia;
} 


\section{Introduction}

People are today the key to economic development and success of the enterprises. The human resource management is seen as the main business and strategic activity, and the compensation management, as one of the main parts of the human resource management, could play an important role in regard to the issues of labour costs and employee motivation.

Compensation management comprises the design, implementation and maintenance of the payment system, which helps the enterprise to realize its aims. In order to be able to do that, the reward system has to be designed adequately, and at the same time it has to be fair, objective and initiative, too. The salary is namely a very sensitive category, because it represents the compensation for the work done and for the individual contribution of the employees. Apart from that, the compensation system to be accepted in the enterprise has to satisfy the employees needs for recognition and to enable them to be well informed about all its characteristics through a good information and communication network. The motivation character of the salaries, the possibilities given by the adequate compensation to find solutions in critical situations as well as the increase in efficiency and enterprises competitiveness have to be considered constantly.

In all Newly Industrializing Countries, as well as in Croatia, the compensation management is not sufficiently valued concerning the role it plays in achieving the enterprise`s aims. Among the numerous changes in the transitional process caused by the introduction of the market economy, privatisation, development of the enterpreneurship and similar factors, the reward system was unjustifiably neglected and the market economy principles are not applied in this issue very often. This fact is particularly interesting and worth an analysis if we take into consideration that just in the countries with lower living standards, the motivation character of the wages has been revealed.

\section{The importance of the compensation management for prosperity, efficiency and competitiveness of the enterprises}

The primary aim of the compensation management is to increase the work efficiency and performance of the employees in order to promote the business process and to improve the business results of the enterprise (Armstrong, Murlis, 1988). Although all the components of the compensation management are important for the realization of this basic aim, we are convinced that special care has to be taken for the designing of an adequate payment policy as to the possibilities of incentive and alternative reward.

The compensation policy ensures the development of various components of the payment system to be directed in achieving its general and special aims. In order to design the compensation policy correctly, managers have to set off from the 
following questions (Greenhill, 1990): How many jobs are there or should be in the enterprise? What is the relative value of the defined job in comparison with other jobs? What is the influence of the external factors on wages level? What relations should the pay structure have concerning the ratio of the basic wages and the incentive part of the wages? What is the internal and external demand for staff profile necessary in the enterprise? etc. Each enterprise creates the compensation policy according to the kind of the activities undertaken, to products, to technological process, to organizational culture, to the surroundings in which it operates and to other specific needs. At the same time attention has to be paid to internal and external factors which influence the salaries level.The most important are: relative work complexity, performance, market and trade union pressure.

It is very important for the enterprise to decide which behaviour and working contribution it is going to initiate by the payment policy, because there are many possibilities, such as: quantity, quality, presence at work, loyalty, responsibility etc. This way, the compensation management can direct the efforts of the employees towards greater productivity, better efficiency, greater competitiveness and other strategic aims of the enterprise, and it can also surpass or overcome different critical situations, in which the enterprise might be, due to the impossibility to realize the planned production quantity, insufficient product quality, absence of employees from work, great fluctuations or a lack of responsibility.

Payment policy must be in accordance with the situation in which the enterprise operates as well as with the plans for its development in thefuture. This means that the payment policy presents the basis of the payment strategy which must be formulated in a way that enables the achieving of long term aims set to the payment system, but also the aims defined by the needs of the personal and business policy of the enterprise. Based on the evaluation of advantages and weak points of the own enterprise, as well as on the opportunities and threats which the enterprise experiences on the market, the compensation strategy can help to foresee and avoid possible critical situations which the enterprise might face, as well as to benefit from the enterprise's strengths to realize possible favourable occasions and to increase its competitiveness.

One of the very important areas of compensation policy is the incentive payment. The compensation, which has in general a very high position on the scale of the factors that motivate the working behaviour, and all the motivation theories acknowledge its specific influence on the performance of the employees and their efficiency. The incentive payment plans have an especially great motivation strength, as they guarantee that the employees will be adequately paid for more qualitative and more effective work. In order to reveal the motivation character fully, the incentive payment plans must satisfy certain demands: 
1) the established performance standards must be realistic and possible to achieve

2) a clear connection must exist between the work results and the incentive part of the payment

3) the compensation system must be based more on the positive consequences of the work behaviour than on the negative ones

4) the increase in the incentive part of the wages resulting from greater efficiency must be high enough to justify the additional effort exerted

5) the increase in payment should follow the increase in performance as straight as possible.

Apart from that, the motivation strength of the incentive payment plans depends also on the share of the incentive part of the salary in the total salary. (Galetić, Pavić, 1996). The compensation systems have the greatest motivation strength, by which the payment completely depends on the realized performance, but due to the possible negative influences and the overwork of the employees, various combinations of incentive payment plans with partly fixed salaries do in fact lead to the best results. The least incentive payment is the fixed salary.

The incentive part of the wages can be estimated by measuring or evaluating. Measuring gives more precise results, and it is mostly used for the employees who work on norm. It should be stressed that the premium payment system has considerable advantages in relation to the piecework system: it can influence the quality, economy, terms etc., and at the same time it also stimulates the realization of greater quantity. For the employees, whose work results are difficult, impossible or economically unjustified to measure exactly, the incentive part of the payment is estimated by evaluation (Dessler, 1994). It is possible to evaluate it approximately, but it can also be done on the basis of the written estimated criteria, which gives considerably better results and is, due to the greater objectivity, more incentive.

By the combination of different incentive payment plans as well as various shares which incentive part of the wages can have in the total payment, a really great number of possibilities are available to the compensation management, which can have effect on the motivation and the working enthusiasm of the employees, and through it, on the increase in efficiency the enterprise's competitiveness. Enterprises have to take care of incentive pay plans for the managers as well, because only satisfied managers can contribute to the formation of the creative and enthusiastic working atmosphere among their subordinates.

In recent times the compensation management has paid more and more attention to alternative payment systems. The intention of these payment systems is to motivate and to reward the employees for long term growth and enterprise 
prosperity, and to encourage the employees and managers to stay with the enterprise offering them the possibility to accumulate the capital based on the long term success of the firm. Although the popularity of the alternative payment systems can be changed depending on economic conditions and trends, financial possibilities of the enterprise, changes in the tax law and similar factors, it is undoubtedly that the profit sharing, employee stock ownership plans and the stock options represent today unavoidable aspects of the compensation management.

Introducing the alternative payment systems, compensation management has the intention to decrease or remove the problems which are set by turbulent environment, deficiency of the qualified labor force, fluctuation of the employees, diversification of the firm, insufficient manager's strategic orientation etc. Omitting and solving the potential and real critical situations this way, the alternative payment systems are in the function of realization of one of the basic aims of each firm - increase of its efficiency which is confirmed by numerous empirical investigations (Cooke, 1994; Jones, Kato 1995).

How do Croatian enterprises design the compensation policy? Which kind of behaviour and working contribution do they want to stimulate by the existing compensation system? Do they consider wages to be the important motivation factor of the working behaviour? Do they prefer the fixed salaries or the incentive pay plans? Do they apply the profit sharing and the stock option? Do they intend to motivate the managers to work better by a special incentive plan? We have tried to answer these and many other questions during the research which we have conducted in 139 enterprises in the Republic of Croatia. Examining and analyzing the obtained results, we shall try to confirm the basic hypothesis of this study, according to which the Croatian enterprises neither pay enough attention to compensation management, nor do they use the possibilities sufficiently, which the compensation management offers in the sense of an increase in efficiency and the competitiveness of the enterprises.

\section{The study}

The study was conducted during the first three months of 1998 in the Republic of Croatia. The sample covered 600 Croatia enterprises in all branches of the economy. The aim of the sample covers manufacturing service, and trading and financial enterprises. It was attempted to cover small, medium and large firms proportionally. In addition to basic information about the firm, the study questionnaire consisted of 33 questions in the areas of competitive structure, strategy, organizational structure and compensation management. Some questions were of a closed nature with opportunities to choose one or more responses while others were formulated as open questions with complete freedom of response. 
The questionnaire was distributed to top managers of the enterprises in the sample, which is a logical view of the nature of the study. Within 60 days, 139 questionnaires were received (questionnaire return rate: $23,17 \%$ ), which is satisfactory for the purpose of our study. All the questionnaires were filled in by the top people in the enterprises and, in some cases, by their closest colleagues.

It is interesting to note that the enterprises, which returned the questionnaires, employed 106000 people in 1997, gained total revenue of 16 billion US\$ and made total profits of 140 million US\$. Questionnaires were received from 66 manufacturing and 73 non-manufacturing enterprises.

We consider the study sample representative considering that the enterprises examined employ more than $10 \%$ of all employees in Croatia and that the ration between the revenues of manufacturing and non-manufacturing enterprises in the sample is nearly equal to that in the Croatian economy.

For the purposes of this study we identified three groups of enterprises according to the number of employees. The first group, which was labeled „Small enterprises“, consists of enterprises which have fewer than 100 employees, the second group, enterprises with between 100 and 500 employees, was labeled „medium enterprises“ and the third, group enterprises with more than 500 employees, was labeled „large enterprises“. The division is of conditional character and although there was no weighting by total revenue or type of activity, it seems to show clearly the present situation in the Croatian economy. Of the questionnaires returned, 38 were from the enterprises with fewer than 100 employees $(27,3 \%), 51$ from the enterprises between 100 and 500 employees $(36,7 \%)$ and 50 from the enterprises employing more that 500 people $(36,0 \%)$.

\section{Results of the study}

It is encouraging that in $66 \%$ of the enterprises the compensation policy has been systematically and clearly designed. It is significant that considerably greater attention has been paid to compensation policy in large enterprises, where even $85 \%$ of the enterprises seriously deal with these problems, than in small enterprises where only $29 \%$ of them systematically design payment policy. $21 \%$ of the enterprises have a partial and ad hoc designed compensation policy, whereas $13 \%$ of the enterprises consider that the wages can be distributed without systematically designed payment policy. This last attitude has been greatly represented in small enterprises among which even $32 \%$ do not see any need for designing clear payment policy.

The compensation management strategy has been formed in $7 \%$ of the enterprises. It is a question of large enterprises where the compensation strategy consists of a certain number of programs and represents the constituent of human resource management strategy and as such, a constituent of the strategic 
plans of the enterprise. In $11 \%$ of the enterprises the compensation management strategy is partly touched in the human resource development strategy, but it is not worked out in details, while in $82 \%$ of the enterprises there is no strategic orientation in the field of reward.

Table 1. Kinds of behaviour which the enterprises want to achieve by the existing compensation system

\begin{tabular}{|l|c|c|c|c|}
\hline \multirow{2}{*}{$\begin{array}{l}\text { Enterprises } \\
\text { Behavior }\end{array}$} & \multicolumn{4}{|c|}{ \% of enterprises } \\
\cline { 2 - 5 } & $\begin{array}{l}\text { All } \\
\text { enterprises }\end{array}$ & $\begin{array}{l}\text { Small } \\
\text { enterprises }\end{array}$ & $\begin{array}{l}\text { Medium } \\
\text { enterprises }\end{array}$ & $\begin{array}{l}\text { Large } \\
\text { enterprises }\end{array}$ \\
\hline $\begin{array}{l}\text { Increase in quantity and } \\
\text { efficiency }\end{array}$ & 47,5 & 43,3 & 53,3 & 48,1 \\
\hline $\begin{array}{l}\text { Improvement of work } \\
\text { quality }\end{array}$ & 16,5 & 16,7 & 16,0 & 16,7 \\
\hline Presence at work & 1,0 & 0,0 & 0,0 & 1,0 \\
\hline Loyalty to the enterprise & 12,0 & 15,0 & 10,7 & 12,1 \\
\hline Increase in responsibility & 21,0 & 25,0 & 20,0 & 20,6 \\
\hline No defined aims & 0,5 & 0,0 & 0,0 & 0,0 \\
\hline Something else & 1,5 & 0,0 & 0,0 & 1,5 \\
\hline Total & 100,0 & 100,0 & 100,0 & 100,0 \\
\hline
\end{tabular}

By the existing compensation system, the greatest number of the enterprises, $47 \%$ of them, want to achieve an increase in the productivity and in the employees' success. $23 \%$ of the enterprises intend to increase the work quality this way. Only $1 \%$ of the examined enterprises intend to achieve greater presence at work, $12 \%$ of the enterprises want to stimulate the employees to greater loyalty to the enterprise and $21 \%$ of them want to increase the responsibility of the employees. Above all expectations, there is the cognition that only $0,5 \%$ of the enterprises have not defined the aims they would like to realize by the existing payment system. If we take into consideration the enterprises referring to their size, we can conclude that there are no significant differences between small, medium and large enterprises, concerning the 
stimulation of the determined kind of behaviour through the compensation system which they apply.

There is a similar situation when we divide the enterprises into manufacturing and non-manufacturing ones, where a somewhat greater number of the nonmanufacturing ones in comparison to the manufacturing ones $(23.2 \%$ according to $19,4 \%$ ) want to increase the responsibility of their employees by the existing compensation system. By observing the financial results of the year 1997, it can be seen that the enterprises that did not gain any profit want to stimulate, by the reward system, an increase in quantity and in the successfulness of the employees (54\%) and the increase in responsibility of the employees $(27,3 \%)$, and pay less attention to increase in work quality (9\%) than the profitable enterprises.

We were interested in the managers opinions about the importance of particular motivation factors regarding their possibility to stimulate the employees to greater engagement on work. So, we asked the managers to range, referring to the importance, the following motivation factors of the working behaviour from 1 to 9: the height of the basic salary, incentive part of the salaries, good working conditions, good and justified managers, possibilities of promotion, possibilities of further education, possibilities of creative demonstrating, interesting work and good interhuman relations. The greatest number of managers think that the payment represents one of the most important motivation factors for greater engagement of the employees at work. The height of the basic wages is in 53,7\% of the enterprises on the first place on the list of the motivation factors, whereas in $22,9 \%$ of the enterprises it is on the second position. The incentive part of the salary is considered to be the most important motivator of the working behaviour in $25 \%$ of the enterprises, and in $41,2 \%$ of the enterprises it is on the second place. Other motivation factors for working behaviour got an important place from only a small number of managers. Good working conditions are stressed in $31,5 \%$ of the enterprises where they are on the third position, and in $16,9 \%$ of the enterprises they are on the fourth place. Good human relations are on the fourth and fifth place in $40,2 \%$ of the enterprises. It is disturbing that little importance is given to the possibility of promotion, further education, creative demonstration and interesting work. Almost in $50 \%$ of the enterprises the managers set the possibility of promotion on the sixth, seventh or eighth place on the list of the motivation factors of the working behaviour. In $65 \%$ of the cases the possibility of creative demonstration is put by the managers on the last four places concerning the importance, and the interesting work in $69 \%$ of the enterprises is on the fifth, sixth, seventh or eighth place. According to the managers, the employees are not interested in the possibility of further education very much, so it is in $47,4 \%$ of the cases on the last place and in $22,5 \%$ of the cases next to the last motivation factor of the working behaviour. The greatest disagreement among the managers is the 
motivation - good and justified managers. It is equally placed on the list of motivation factors of the working behaviour from the second to the last place.

Table 2: Range of particular motivation factors of the working behaviour of the employees according to the opinion of top managers of the Croatian enterprises

\begin{tabular}{|l|c|c|c|c|c|c|c|c|c|}
\hline $\begin{array}{l}\text { Motivator } \\
\text { range of the } \\
\text { motivators }\end{array}$ & 1 & 2 & 3 & 4 & 5 & 6 & 7 & 8 & 9 \\
\hline $\begin{array}{l}\text { Height of the } \\
\text { basic salary }\end{array}$ & 53,7 & 22,9 & 6,3 & 3,2 & 3,2 & 2,5 & 2,5 & 0,8 & 3,4 \\
\hline $\begin{array}{l}\text { Incentive part } \\
\text { of the salary }\end{array}$ & 25,0 & 41,2 & 9,4 & 8,1 & 4,0 & 2,5 & 1,7 & 5,8 & 1,7 \\
\hline $\begin{array}{l}\text { Good work } \\
\text { conditions }\end{array}$ & 6,6 & 6,1 & 31,5 & 16,9 & 8,0 & 12,5 & 5,1 & 5,8 & 6,9 \\
\hline $\begin{array}{l}\text { Justified mana- } \\
\text { gers }\end{array}$ & 3,7 & 8,4 & 11,0 & 15,3 & 17,6 & 8,3 & 16,2 & 9,2 & 10,3 \\
\hline Promotion & 2,2 & 8,4 & 16,5 & 12,1 & 10,4 & 12,5 & 21,4 & 15,0 & 2,6 \\
\hline $\begin{array}{l}\text { Further educa- } \\
\text { tion }\end{array}$ & 0,0 & 0,8 & 3,1 & 3,2 & 6,4 & 6,7 & 9,4 & 22,5 & 47,4 \\
\hline $\begin{array}{l}\text { Creative } \\
\text { demonstration }\end{array}$ & 1,5 & 3,8 & 4,7 & 11,3 & 14,4 & 17,5 & 14,5 & 18,3 & 14,7 \\
\hline $\begin{array}{l}\text { Interesting } \\
\text { work }\end{array}$ & 3,7 & 2,3 & 8,7 & 9,7 & 16,0 & 22,5 & 17,9 & 13,3 & 6,0 \\
\hline $\begin{array}{l}\text { Good human } \\
\text { relations }\end{array}$ & 3,4 & 6,1 & 8,8 & 20,2 & 20,0 & 15,0 & 11,3 & 9,3 & 7,0 \\
\hline Total & 100,0 & 100,0 & 100,0 & 100,0 & 100,0 & 100,0 & 100,0 & 100,0 & 100,0 \\
\hline
\end{tabular}

The incentive part of the salaries has been estimated in $20,1 \%$ of the enterprises on the basis of the measurements of the working norm fulfillment, in $36,1 \%$ of the enterprises it is estimated on the basis of performance appraisal, and in $27,2 \%$ of the enterprises it is estimated according to the subjective evaluation of the superimposed manager. In $11,2 \%$ of the enterprises the employees get fixed salaries without any bonuses. If we consider the ways of determining the incentive parts of the salary in relation to the size of the enterprise, we can see that there are no great aberrations. Small and medium enterprises are more 
inclined to give fixed salaries than the large ones, and in the large enterprises the connection between the wages and the performance based on the norm measurements is more frequent than in the small and medium ones.

Table 3. Ways of determining the incentive part of the wages (salaries)

\begin{tabular}{|l|c|c|c|l|}
\hline \multirow{2}{*}{ Enterprise Way } & \multicolumn{4}{|c|}{$\%$ of enterprises } \\
\cline { 2 - 5 } & $\begin{array}{l}\text { All } \\
\text { enterprises }\end{array}$ & $\begin{array}{l}\text { Small } \\
\text { enterprises }\end{array}$ & $\begin{array}{l}\text { Medium } \\
\text { enterprises }\end{array}$ & $\begin{array}{l}\text { Large } \\
\text { enterprises }\end{array}$ \\
\hline Norm measurement & 20,1 & 16,3 & 18,6 & 22,2 \\
\hline Performance appraisal & 36,1 & 37,2 & 37,3 & 34,9 \\
\hline $\begin{array}{l}\text { Subjective manager's } \\
\text { evaluation }\end{array}$ & 27,2 & 30,2 & 25,4 & 28,6 \\
\hline Fixed salaries & 11,2 & 11,6 & 15,3 & 6,4 \\
\hline Another way & 5,4 & 4,5 & 3,4 & 7,9 \\
\hline Total & 100,0 & 100,0 & 100,0 & 100,0 \\
\hline
\end{tabular}

Table 4: The way of determining the incentive part of the salaries in manufacturing and non-manufacturing enterprises

\begin{tabular}{|l|c|c|}
\hline \multirow{2}{*}{ Enterprises Way } & \multicolumn{2}{|c|}{$\%$ of enterprises } \\
\cline { 2 - 3 } & $\begin{array}{l}\text { Manufacturing } \\
\text { enterprises }\end{array}$ & $\begin{array}{l}\text { Non-manufacturing } \\
\text { enterprises }\end{array}$ \\
\hline Norm measurement & 22,1 & 17,3 \\
\hline Performance appraisal & 36,0 & 37,0 \\
\hline Subjective manager's evaluation & 27,9 & 29,6 \\
\hline Fixed salaries & 8,2 & 14,9 \\
\hline Other way & 5,8 & 1,2 \\
\hline TOTAL & 100,0 & 100,0 \\
\hline
\end{tabular}

It is amazing that manufacturing and non-manufacturing enterprises do not differ from each other considerably concerning the ways of determining the 
incentive part of the wages. In manufacturing enterprises norm measurement is used in some more cases $(22,1 \%)$ in determining the incentive part of the wages than in non-manufacturing enterprises $(17,3 \%)$ and $14,9 \%$ of the nonmanufacturing enterprises apply the fixed salaries in contrast to the manufacturing enterprises where they are represented in only $8,2 \%$ of the cases. The tendency to all kinds of evaluations for determining the incentive parts of the salaries is the same in manufacturing and non-manufacturing enterprises.

Table 5: Ways of determining the incentive part of the salaries with regard to the profitability of the enterprise field of activity

\begin{tabular}{|l|c|c|c|c|c|c|}
\hline $\begin{array}{l}\text { Way } \\
\text { Profitability of } \\
\text { the activity }\end{array}$ & $\begin{array}{l}\text { Norm } \\
\text { measure- } \\
\text { ment }\end{array}$ & $\begin{array}{l}\text { Perfor- } \\
\text { mance } \\
\text { appraisal }\end{array}$ & $\begin{array}{l}\text { Subjective } \\
\text { manager's } \\
\text { evaluation }\end{array}$ & $\begin{array}{l}\text { Fixed } \\
\text { salary }\end{array}$ & $\begin{array}{l}\text { Another } \\
\text { way }\end{array}$ & Total \\
\hline $\begin{array}{l}\text { Low } \\
\text { profitability } \\
\text { and no } \\
\text { profitability }\end{array}$ & 15,8 & 36,8 & 31,6 & 15,8 & 0,0 & 100,0 \\
\hline $\begin{array}{l}\text { Profitability } \\
\text { less than } \\
\text { approximate } \\
\text { one in } \\
\text { Croatian } \\
\text { economy }\end{array}$ & 20,0 & 45,7 & 14,3 & 17,1 & 2,9 & 100,0 \\
\hline $\begin{array}{l}\text { Profitability } \\
\text { corresponding } \\
\text { to the Croatian } \\
\text { approxima- } \\
\text { tion }\end{array}$ & 21,5 & 40,0 & 23,1 & 7,7 & 7,7 & 100,0 \\
\hline $\begin{array}{l}\text { Profitability } \\
\text { above the } \\
\text { approxima--- } \\
\text { tion }\end{array}$ & 25,0 & 25,0 & 35,7 & 10,7 & 3,6 & 100,0 \\
\hline
\end{tabular}

We wanted to find out if the ways of determining the incentive part of the salaries differ in the enterprises which have the profitable activity from the enterprises with a non-profitable one. Enterprises with low profitable or non profitable activity use somewhat less the measurement of performance for determining the incentive part of the wages from other enterprises, and they are inclined to fixed salaries, too. The performance appraisal is particularly pointed 
out in the enterprises whose business activity corresponds to the Croatian average in profitability $(40 \%)$ or it lies under the average $(45,7 \%)$. The enterprises which are above the average business profitability, determine the incentive part of the salaries on the basis of norm measurement in $25 \%$ of the cases, and in $35 \%$ of the cases they determine it on the basis of subjective evaluation of the manager.

Profit sharing was applied once or several times in $18 \%$ of the Croatian enterprises and $16,7 \%$ of the enterprises have quoted that they think of introducing the profit sharing, because it helps in approaching the interests of the employees and employers, in developing greater understanding of the employees for the necessity of the profit making and investment, in developing the participation style of management, and in giving incentive to the employees to stay with the enterprise (Schneider, Zander 1993). It is particularly interesting that in small enterprises in much more cases $(26,3 \%)$ profit sharing is used than in large enterprises $(12,8 \%$ of the cases). From the enterprises which realized positive financial results in 1997, 21,7\% gave part of their profit to their employees.

Table 6: Application of the profit sharing in Croatian enterprises

\begin{tabular}{|c|c|c|c|c|}
\hline \multirow[b]{2}{*}{$\begin{array}{l}\text { Enterprises Profit } \\
\text { sharing }\end{array}$} & \multicolumn{4}{|c|}{$\%$ of enterprises } \\
\hline & $\begin{array}{l}\text { All } \\
\text { enterprises }\end{array}$ & $\begin{array}{l}\text { Small } \\
\text { enterprises }\end{array}$ & $\begin{array}{l}\text { Medium } \\
\text { enterprises }\end{array}$ & $\begin{array}{l}\text { Large } \\
\text { enterprises }\end{array}$ \\
\hline Yes & 18,1 & 26,3 & 17,7 & 12,8 \\
\hline No & 65,2 & 63,2 & 66,7 & 63.8 \\
\hline It is thought of & 16,7 & 10,5 & 15,6 & 23,4 \\
\hline TOTAL & 100,0 & 100,0 & 100,0 & 100,0 \\
\hline
\end{tabular}

In $30 \%$ of the examined cases the employees hold shares of their enterprise. This is the result of the privatization process of the enterprises, where the employees had the right to buy the shares of the enterprise they were employed in at a reduced price, up to the sum of 20000 DEM. But the possibility for the employees to buy a certain number of shares each year at the lower price than the price on the market has not been noticed in any of the examined enterprises. In two enterprises with a large number of employees it was pointed out that that possibility was thought about.

As the working climate in the enterprise, and very often the acceptance of the determined payment system ,too, depend greatly on the behaviour and attitudes 
of the manager, we were interested in how the manager's salaries were determined and how they were stimulated for more effective work.

Salaries based on the annual contract were given to top managers in $44,9 \%$ of the enterprises, whereas in $24,7 \%$ of the enterprises annual contracts were signed by managers on top and middle levels. In $23,9 \%$ of the enterprises managers do not get salaries based on the contract, and in a smaller number of enterprises various other combinations were used. If we observe only great enterprises, we can see that there is a really great tendency to estimate the managers' salaries on the basis of annual contract. In $50 \%$ of the large enterprises the top managers get the salaries based on the annual contract, and in $39,6 \%$ of the large enterprises the salaries have been determined this way for the top and middle level managers. Only in $6,3 \%$ of the large enterprises the annual contracts for determining the manager's salaries have not been used at all.

Table 7: Managers who get salaries based on the annual contract

\begin{tabular}{|l|c|c|}
\hline \multirow{2}{*}{ Enterprises Annual contract } & All enterprises & Large enterprises \\
\cline { 2 - 3 } Only top managers & 44,9 & 50,0 \\
\hline Top and middle level managers & 24,7 & 39,6 \\
\hline Nobody gets it & 23,9 & 6,3 \\
\hline Some other combination & 6,5 & 4,1 \\
\hline TOTAL & 100,0 & 100,0 \\
\hline
\end{tabular}

If we observe the differences in the way how managers ' salaries are determined between manufacturing and non-manufacturing enterprises, we can see that the medium level managers get the salaries based on the annual contract in more manufacturing enterprises $(32,3 \%)$ than in the non-manufacturing ones $(17,8 \%)$. Even in $31,5 \%$ of the non-manufacturing enterprises, the managers do not get the salary based on the annual contract, while this percentage is half less in the manufacturing enterprises $(15,4 \%)$.

For good work, managers are rewarded in $23,2 \%$ of the enterprises by an annual bonus, in $13,9 \%$ of the enterprises they are stimulated by different benefits such as firm's car, acceptable credits for flats etc., and in $6 \%$ of the enterprises stock option is applied. $38,4 \%$ of the enterprises have no stimulating mechanisms for their managers. Small enterprises most often reward their managers for a good work. In $28,6 \%$ of the cases they use annual bonus, and in $26,2 \%$ of the cases, they use some other benefit for the managers. Medium enterprises are less 
inclined to stimulate the managers, $44,2 \%$ of them do not use any incentive plans, while annual bonus is applied in $19,2 \%$ of the cases, and various other benefits in $11,5 \%$ of the cases. It is amazing that even $40 \%$ of the large enterprises do not stimulate the managers for efficient behaviour and better work, and only in 5,5\% of the cases various benefits are used for this purpose. Stock option has mostly been applied in large enterprises (in 9,1\% of the cases) and less in the small enterprises (in 2,4\%of the cases).

Table 8: Managers getting the salaries based on the annual contract in manufacturing and non-manufacturing enterprises

\begin{tabular}{|l|c|c|}
\hline \multirow{2}{*}{$\begin{array}{l}\text { Enterprises Annual } \\
\text { contract }\end{array}$} & $\begin{array}{c}|c| \\
\text { Manufacturing } \\
\text { enterprises }\end{array}$ & $\begin{array}{c}\text { Non-manufacturing } \\
\text { enterprises }\end{array}$ \\
\cline { 2 - 3 } Only top managers & 44,6 & 45,2 \\
\hline $\begin{array}{l}\text { The highest and medium } \\
\text { level managers }\end{array}$ & 32,3 & 17,8 \\
\hline Nobody gets it & 15,4 & 31,5 \\
\hline Some other combinations & 7,7 & 5,5 \\
\hline TOTAL & 100,0 & 100,0 \\
\hline
\end{tabular}

If we observe the incentive plans for managers in the manufacturing and nonmanufacturing enterprises, we can see that annual bonus is used more often in non-manufacturing enterprises $(29,8 \%)$ than in manufacturing ones $(16,9 \%)$. Apart from that, $42,3 \%$ of the manufacturing enterprises do not use any methods for the reward and stimulation of their managers, whereas this is the case in $34,5 \%$ of the non-manufacturing enterprises. Even greater differences exist between the enterprises with realized positive or negative financial results in 1997. The enterprises with the negative financial result have no incentive plans for their managers in $61,1 \%$ of the cases and only $11,1 \%$ of them use annual bonus. In the enterprises with the positive financial result, the percentage of the enterprises using incentive plans for the managers is twice as much $(32,1 \%)$, and the annual bonus is applied in $26,9 \%$ of the enterprises, stock distribution is applied in $3,4 \%$ of the enterprises, stock option in $7,7 \%$ of the enterprises and various other benefits in $12,8 \%$ of the enterprises which were working with profit. 
Table 9: Incentive plans for managers in Croatian enterprises

\begin{tabular}{|l|c|c|l|l|}
\hline \multirow{2}{*}{$\begin{array}{l}\text { Enterprises } \\
\text { Incentive plan }\end{array}$} & $\begin{array}{l}\text { All } \\
\text { enterprises }\end{array}$ & $\begin{array}{l}\text { Small } \\
\text { enterprises }\end{array}$ & $\begin{array}{l}\text { Medium } \\
\text { enterprises }\end{array}$ & $\begin{array}{l}\text { Large } \\
\text { enterprises }\end{array}$ \\
\hline Annual bonus & 23,2 & 28,6 & 19,2 & 23,6 \\
\hline Stock distribution & 5,3 & 4,8 & 5,8 & 3,6 \\
\hline Stock option & 6,6 & 2,4 & 5,8 & 9,1 \\
\hline Various benefits & 13,9 & 26,2 & 11,5 & 5,5 \\
\hline No stimulation & 38,4 & 31,0 & 44,5 & 40,0 \\
\hline Something else & 12,6 & 7,0 & 13,5 & 18,2 \\
\hline TOTAL & 100,0 & 100,0 & 100,0 & 100,0 \\
\hline
\end{tabular}

Table 10: Incentive plans for managers in manufacturing and nonmanufacturing enterprises

\begin{tabular}{|l|c|c|}
\hline \multirow{2}{*}{$\begin{array}{l}\text { Enterprises Incentive } \\
\text { plan }\end{array}$} & \multicolumn{2}{|c|}{ \% of enterprises } \\
\cline { 2 - 3 } & Manufacturing enterprises & $\begin{array}{c}\text { Non-manufacturing } \\
\text { enterprises }\end{array}$ \\
\hline Annual bonus & 16,9 & 29,8 \\
\hline Stock distribution & 1,4 & 8,3 \\
\hline Stock option & 7,0 & 6,0 \\
\hline Various benefits & 12,7 & 14,3 \\
\hline No stimulation & 42,3 & 34,5 \\
\hline Something else & 19,7 & 7,1 \\
\hline TOTAL & 100,0 & 100,0 \\
\hline
\end{tabular}

\section{Discussion and conclusion}

The motivation character of the salaries enables the enterprise to influence its prosperity and to increase its efficiency and competitiveness by fair and 
systematic compensation management. Although all the areas of compensation management in this process play an important role, special attention has to be paid to the design of compensation policy and to the incentive and alternative payment plans.

Based on the results of the study conducted in the enterprises in the Republic of Croatia, we have come to the conclusion that the managers in all the enterprises generally approach to the issues of compensation management the same way, with no regard to the enterprise's size or activity. The study has shown that the majority of Croatian enterprises have a systematic and clearly designed compensation policy or at least that they partly take care of it. However, after the detailed analysis of special areas of the compensation policy, the question is set about the quality of compensation policy in Croatian enterprises due to the following facts:

- by the existing ways of payment a relatively small number of the enterprises aim to achieve greater loyalty to the enterprise and greater responsibility of the employees, although there are crucial problems of the compensation management in the existing turbulent business conditions.

- $82 \%$ of the enterprises have no strategy orientation in the field of reward

- from the total number of the enterprises which use the evaluation for estimating the incentive part of the wages, almost $50 \%$ base this evaluation on the personal estimation of the manager, which, because of the lack of the objective criteria, can considerably degrade the motivation role of incentive plans and can cause dissatisfaction of the employees about compensation system

- in $81 \%$ of the enterprises profit sharing is not applied, and the great majority of them has no intention to introduce it, although it can influence the performance of the employees and their loyalty to the enterprise

- employee stock ownership plans are mainly based on possessing shares obtained in the process of privatization

- in a quarter of Croatian enterprises the top managers do not get salaries based on the annual contracts. It means that the level of these salaries is relatively low and inadequate to their responsibility

- more than one third of the Croatian enterprises do not use any incentive plans for managers, although combining the managers' work results with the success of the enterprise can considerably contribute to the prosperity of the enterprise

- annual bonus as a short term incentive for the more efficient work of the managers is used only in $23,2 \%$ of the enterprises 
- stock option as the long term incentive and the possibility to combine the interests of the top managers with the strategic prosperity of the enterprise is used in only $6,6 \%$ of the enterprises.

Unfortunately the presented study is the first investigation of that kind in Croatia and there is no possibility of comparison the obtained results with the results of the previous studies. The fact is, however, that the average salary in Croatia is on a rather low level (700 DEM net per month). If we combine this fact with the present results, it can be concluded that Croatian enterprises do not use enough possibilities which compensation management offers in regard to the increase of efficiency and competitiveness of the enterprises. The more frequent application of the various systems would not possibly considerably increase the generally law average pay level, but the employees would have the feeling that the greater dedication to work results in higher pay. That would satisfy the employees needs for justice conserning the pay system, and also, it can considerably improve their satisfaction on work and add to creation of incentive work environment in the enterprise.

One of the reasons for such a situation is the insufficient attention paid to the compensation system, as well as the neglecting of the positive effects which the adequate attitude to the payment system can have on the business results of the enterprise. We think that the explanation for such conditions can be found in the unfinished process of transition and privatization, orientation to solve current business problems, low financial liquidity of the enterprises, high rate of unemployment (18\%), bad trade union organization, weak strategic enterprise orientation, negative attitude to the employees participation, lack of law regulations of the alternative ways of payment etc. Apart from that, the employees are not considered to be the most important capital in the great majority of Croatian enterprises and human resource management is not seen as the key business and strategic activity, which all influences unjustified neglecting of the reward system. The consequences of all that are inconceivability and non-utilisation of the possibilities which compensation management can give while increasing the efficiency and competitiveness of the enterprise, as well as avoiding or overcoming the problematic situations in the enterprise.

In spite of the current situation, it seems that many facts point out the better prospects of the compensation management in Croatian enterprises. Almost all the enterprises have clearly determined the aims they want to achieve by the compensation system. The relations between the salaries determined on the basis of measurements and evaluations and fixed salaries, follow development direction of these relations in the developed countries, and the modern incentive plans for the employees and the managers, such as profit sharing, annual bonus, stock opinion etc. are also applied in a certain number of the Croatian enterprises. As the top managers in $79 \%$ of the examined cases consider the 
salaries to be the basic motivation factor of the working behaviour, in the conditions in which the Croatian enterprises lead the business today, they can be expected to be more engaged in more adequate designing and carrying out the compensation policy in their enterprises. Because of that, we expect that the research results of the compensation management in Croatian enterprises, which we intend to carry out in near future, will be considerably better than the ones presented in this paper.

\section{References}

Armstrong M., Murlis H., (1988); Reward Management, Kogan Page Ltd., London

Cook W.N., (1994): Employee Participation Programs, Group-based Inventives and Company Performances: A Union Nonunion Comparison, Industrial and Labor Relations Review, Vol 47, No. 4 pp. 594-609.

Dessler G., (1994): Human Resources Management, Prentice Hall Englawood Cliffs, New Jersey

Galetić L., Pavić I., (1996): Upravljanje plaćama, PRIF, Zagreb

Greenhill R.I., (1990): Performance Related Pay for the 1990s, Fitzwilliam Publishing Ltd. Cambridge

Jones D.C., Kato T:, (1995): The Productivity Effects of Employee Stock-Ownership Plans and Bonuses: Evidence from Japanese Panel Data, American Economic Review, Vol. 85, No 3, pp. $391-414$

Schneider H. J., Zander E., (1993): Erfolgs- und Kapitalbeteiligung der Mitarbeiter in Kleinund Mittelbetrieben, Freiburg in Breisgau 